\title{
Development of an AAV9-RNAi-mediated silencing strategy to abrogate TRPM4 expression in the adult heart
}

\author{
Rebekka Medert ${ }^{1,2}$ (1) $\cdot$ Andreas Jungmann ${ }^{2,3} \cdot$ Staffan Hildebrand $^{4} \cdot$ Martin Busch $^{2,3} \cdot$ Dirk Grimm $^{5,6} \cdot$ Veit Flockerzi $^{7}$. \\ Oliver J. Müller ${ }^{8,9} \cdot$ Patrick Most $^{2,3} \cdot$ Dagmar Schumacher $^{1,2} \cdot$ Marc Freichel $^{1,2}$
}

Received: 30 September 2020 / Revised: 5 January 2021 / Accepted: 11 January 2021 / Published online: 13 February 2021

(C) The Author(s) 2021

\begin{abstract}
The cation channel transient receptor potential melastatin 4 (TRPM4) is a calcium-activated non-selective cation channel and acts in cardiomyocytes as a negative modulator of the L-type $\mathrm{Ca}^{2+}$ influx. Global deletion of TRPM4 in the mouse led to increased cardiac contractility under $\beta$-adrenergic stimulation. Consequently, cardiomyocyte-specific inactivation of the TRPM4 function appears to be a promising strategy to improve cardiac contractility in heart failure patients. The aim of this study was to develop a gene therapy approach in mice that specifically silences the expression of TRPM4 in cardiomyocytes. First, short hairpin $\mathrm{RNA}^{\mathrm{miR} 30}$ (shRNA ${ }^{\mathrm{miR} 30}$ ) sequences against the TRPM4 mRNA were screened in vitro using lentiviral transduction for a stable expression of the shRNA cassettes. Western blot analysis identified three efficient shRNA ${ }^{\text {miR30 }}$ sequences out of six, which reduced the endogenous TRPM4 protein level by up to $90 \pm 6 \%$. Subsequently, the most efficient shRNA ${ }^{\text {miR } 30}$ sequences were delivered into cardiomyocytes of adult mice using adeno-associated virus serotype 9 (AAV9)-mediated gene transfer. Initially, the AAV9 vector particles were administered via the lateral tail vein, which resulted in a downregulation of TRPM4 by $46 \pm 2 \%$. Next, various optimization steps were carried out to improve knockdown efficiency in vivo. First, the design of the expression cassette was streamlined for integration in a self-complementary AAV vector backbone for a faster expression. Compared to the application via the lateral tail vein, intravenous application via the retro-orbital sinus has the advantage that the vector solution reaches the heart directly and in a high concentration, and eventually a TRPM4 knockdown efficiency of $90 \pm 7 \%$ in the heart was accomplished by this approach. By optimization of the shRNA ${ }^{\text {miR30 }}$ constructs and expression cassette as well as the route of AAV9 vector application, a 90\% reduction of TRPM4 expression was achieved in the adult mouse heart. In the future, AAV9RNAi-mediated inactivation of TRPM4 could be a promising strategy to increase cardiac contractility in preclinical animal models of acute and chronic forms of cardiac contractile failure.
\end{abstract}

Keywords Transient receptor potential (TRP) channel · TRPM4 · Adeno-associated virus serotype 9 (AAV9) $\cdot$ RNAi $\cdot$ Gene therapy

This article is part of the special issue on Calcium Signal Dynamics in Cardiac Myocytes and Fibroblasts: Mechanisms in Pflügers Archiv-

European Journal of Physiology

Marc Freichel

marc.freichel@pharma.uni-heidelberg.de

1 Institute of Pharmacology, Heidelberg University, Heidelberg, Germany

2 DZHK (German Centre for Cardiovascular Research), partner site Heidelberg/Mannheim, Heidelberg, Germany

3 Department of Internal Medicine III, Cardiology, University Hospital Heidelberg, Heidelberg, Germany

4 Institute of Pharmacology and Toxicology, University Clinic of Bonn, Bonn, Germany
5 Department of Infectious Diseases/Virology, BioQuant, Medical faculty, Heidelberg University, Heidelberg, Germany

6 DZIF (German Centre for Infection Research), partner site Heidelberg, Berlin, Germany

7 Institute of Experimental and Clinical Pharmacology and Toxicology, Center for Molecular Signaling (PZMS), Saarland University, Homburg, Germany

8 Department of Internal Medicine III, University of Kiel, Kiel, Germany

9 DZHK (German Centre for Cardiovascular Research), partner site Hamburg/Kiel/Lübeck, Kiel, Germany 


\section{Introduction}

TRPM4 is a $\mathrm{Ca}^{2+}$-activated, non-selective cation channel whose expression has been detected in the human heart as well as in the atrium and ventricle of the mouse [18, 22]. In humans, gain-of-function mutations of the Trpm 4 gene are strongly associated with familial arrhythmia syndromes such as Brugada syndrome and progressive familial heart block type I $[17,20,35]$. Previous studies showed that TRPM4deficient mice have an increased $\beta$-adrenergic response compared to wild-type mice [23]. In pressure-volume (PV-loop) measurements, $\beta$-adrenergic stimulation with isoproterenol (ISO) resulted in an increased left ventricular contractility compared to control animals. In vitro studies on isolated cardiomyocytes indicated that TRPM4 deficiency is associated with a faster repolarization of the action potential and an increased $\mathrm{Ca}^{2+}$ influx via L-type channels with isoproterenol stimulation [23]. Recently, we could show that the increased ISO-evoked inotropy and elevated $\mathrm{Ca}^{2+}$ transient can only be observed in TRPM4-deficeint mice on the 129SvJ genetic background and the TRPM4 protein expression level is about $80 \%$ higher in wild-type $129 \mathrm{SvJ}$ mice than in mice with $\mathrm{C} 57 \mathrm{~B} / 6 \mathrm{~N}$ background [26]. The results of this study indicate that the relevance of TRPM4 for cardiac contractility depends on homeostatic TRPM4 expression levels or the genetic background of different mouse strains. Studies of cardiac contractility on isolated left ventricular papillary muscles also showed an increased contractile force in the papillary muscle of $\mathrm{TRPM}^{-/-}$mice compared to wild-type controls under $\beta$ adrenergic stimulation [37]. In the same study, it was additionally observed that the activation of adenylate cyclase in the papillary muscle of the TRPM $4^{-/-}$mouse resulted in a stronger contraction force than in papillary muscles of wild-type controls. In summary, both studies suggest that TRPM4 reduces the driving force for $\mathrm{Ca}^{2+}$ to enter cells via the L-type $\mathrm{Ca}^{2+}$ channels [23, 37]. From a translational point of view, inactivating cardiac TRPM4 function in cardiomyocytes is a promising approach to increase the ventricular contractility of the heart. Blocking cardiac TRPM4 function, especially at elevated catecholamine levels, as they occur in patients with chronic heart failure, could lead to an improvement in cardiac function. So far, there are no small compounds blocking TRPM4 channels with sufficient specificity. However, if such TRPM4 blockers existed, adverse effects could be expected from ubiquitous TRPM4 inactivation arising from other TRPM4-expressing cell types. Blocking the TRPM4 channel in chromaffin cells of the adrenal medulla could lead to hypertension, in mast cells to increased release of proinflammatory substances, and in immune cells to increased activation $[22,38]$. Therefore, molecular inhibition of TRPM4 biosynthesis using RNA interference (RNAi) in combination with viral vector delivery to defined cell types is a suitable alternative to modify TRPM4 function in selected organ functions. Today, targeted RNAi strategies not only are used in basic research to downregulate gene expression, but also are becoming increasingly important for therapeutic use to inhibit expression of pathological relevant genes by harnessing the endogenous RNAi processing pathway [1, 13]. Classical short hairpin RNAs (shRNAs) under the control of strong RNA Pol III promoters can lead to saturation of the endogenous miRNA processing pathway, resulting in downregulation of endogenous miRNAs that fulfill vital functions $[9,11]$. shRNAs embedded in an miRNA background (shRNA ${ }^{\mathrm{miR}}$ ) enable the shRNA sequence to be transcribed efficiently by a tissue-specific RNA Pol II promoter. In contrast to Pol III promoter-driven shRNAs, less toxic effects were observed when using shRNA ${ }^{\mathrm{miR}}$ constructs $[5,24]$. This may be due to weaker RNA Pol II promoters, which lead to a lower expression level of the shRNA ${ }^{\text {miR }}$ cassette. Overall, the artificial shRNA ${ }^{\mathrm{miR}}$ has an improved safety profile compared to classic shRNA, which is particularly important for gene therapy approaches. Because of the short DNA sequence and the simple design, shRNA and shRNA ${ }^{\mathrm{miR}}$ expression cassettes can be packaged in AAV vectors to ensure stable and long-term expression in non-dividing cells [10]. For targeting of the myocardium in rodents, the AAV serotype 9 is particularly well suited after intravenous administration via the tail vein, evidenced by the finding that an AAV9 dose of $10^{11}$ vector genome copies per mouse typically results in robust transduction of over $90 \%$ of the cardiomyocytes in the mouse heart $[14,34]$. However, it should be noted that AAV9 transduction is not limited to cardiomyocytes, and that other organs including the liver and brain can also be transduced to a high extent [43]. By using a cardiomyocyte-specific promoter, expression can be further restricted to cardiomyocytes [27, 32, $34,41]$.

The aim of our work was to develop a highly efficient therapeutic AAV9-RNAi strategy to abrogate TRPM4 expression in the adult heart.

\section{Methods}

\section{Plasmid construction}

Four commercially available shTRPM $4{ }^{\mathrm{miR} 30}$ (\#1-\#4) constructs from Thermo Scientific (USA) were selected and delivered in a lentiviral pGIPZ vector. shTRPM $4{ }^{\text {mir-30 }}$ sequences (Table S1) were flanked by recognition sites for the restriction enzymes XhoI (5') and MluI (3'), to facilitate an exchange of the specific stem sequences. Two additional shTRPM $4^{\text {mir-30 }}$ (\#5-\# 6) constructs were generated. Their sequences were derived from commercially available shRNAs (shRNA-\#5 TRCN0000068684, shRNA-\#6 - TRCN0000068687, Sigma, USA), and the sequence of shRNA \#5 has already been shown to mediate robust downregulation of TRPM4 in 
mouse cells $[29,30]$. The stem sequences of the two shRNAs were synthesized and cloned into the pGIPZ vector via a directed ligation using the flanking restriction enzyme recognition sites XhoI ( $5^{\prime}$ ) and MluI ( $\left.3^{\prime}\right)$. In a negative control vector, the shRNA ${ }^{\text {miR30 }}$ sequence was removed using XhoI and MluI.

The shTRPM $4{ }^{\mathrm{miR} 30}$-tandem cassettes, containing shTRPM $44^{\mathrm{miR} 30}$-\#3 and shTRPM $4{ }^{\mathrm{miR} 30}$-\#4, were synthesized with the restriction site XhoI ( $5^{\prime}$ direction) and SalI ( $3^{\prime}$ direction). The eGFP cDNA was PCR amplified containing the restriction sites XhoI (5') and SalI (3'). Next, the shTRPM $4{ }^{\text {miR } 30}$-tandem cassettes of the PCR-amplified eGFP were subcloned an XhoI-cut and SalI-cut scAAV recipient plasmid [4]. In addition, the expression cassettes comprising three different classic shRNAs against TRPM4 (shTRPM4-\#7, shTRPM4-\#8, and shTRPM4-\#4) under the control of three different Pol III promoters were synthesized. shTRPM4\#-4 has the same sense sequence as shTRPM $4{ }^{\mathrm{mir} 30}$ \#4. The other two shRNAs (shTRPM4-\#7, shTRPM4-\#8) were generated via the online programs siRNA Wizard (https://www.invivogen.com/sirnawizard/) and Block-it RNAi Designer (https://rnaidesigner. thermofisher.com/rnaiexpress/rnaiDesign.jsp). Again, the expression cassette including the restriction sites XhoI (5' direction) and SalI (3' direction) was synthesized and subcloned into the EcoRI-cut and SalI-cut scAAV backbone.

\section{Generation and quantification of AAV9 viral particles}

Recombinant AAV9 (rAAV9) vector particles were generated and purified using the iodixanol gradient ultracentrifugation method $[8,44]$. The rAAV9 production was carried out using HEK293T cells. First, $1.8 \times 10^{8}$ HEK293T cells were seeded in a ten chamber CellStack ${ }^{\circledR}$ (Corning, USA) and cultured in DMEM+Glutamax (Gibco, Thermo Fisher Scientific, USA) supplemented with $10 \%$ fetal bovine serum (FBS) and $1 \%$ Pen/Strep. After $48 \mathrm{~h}$, a 1:1 molar ratio of rAAV vector plasmid and the rep-cap AAV9 helper plasmid (pDP9rs) was mixed and transfected using polyethyleneimine (PEI). The cells were harvested in $3 \mathrm{ml}$ lysis buffer and lysed by four freeze-thaw cycles $72 \mathrm{~h}$ after transfection. The vector particles were purified using an iodixanol gradient consisting of four phases with decreasing density $(60 \%, 40 \%, 25 \%, 15 \%)$ and ultracentrifugation at $50.000 \mathrm{~g}$ for $135 \mathrm{~min}$ at $4{ }^{\circ} \mathrm{C}$. Approximately $3 \mathrm{ml}$ of the $40 \%$ phase, in which predominantly full virus particles accumulate, was recovered with a $27 \mathrm{G}$ needle. Finally, the vector solution was buffered into PBS using dialysis tubes (Zeba Spin Desalting Columns 7K MWCO, Thermo Scientific, USA) and concentrated (VivaSpin 10K MWCO, Sartorius, Germany). Vector titer was determined by quantifying vector genomes using a qPCR SYBR-Green assay (Biorad) and primers listed in Table S2 [16].

\section{Mouse experiments and genotyping}

Experimental procedures were approved by the Regierungspräsidium Karlsruhe according to the Tierschutzgesetz (T-64/18, G-89/15). TRPM4-deficient mouse lines were described previously [38] and housed at the Interfaculty Biomedical Faculty (IBF) Heidelberg. Mice were kept under specified pathogen-free conditions on a 12-h light/12-h dark cycle with water and standard food (Rod18, LASvendi GmbH, Germany) available ad libitum. Injections of AAV9 at $3 \times 10^{12}$ vector genomes per mouse (vg/mouse) were performed in 3-week to 8-week-old male mice. Tail vein (TV) injections were performed in conscious-restrained mice by injecting $200 \mu \mathrm{l}$ vector solution into the lateral vein. Retroorbital sinus injections of $100 \mu \mathrm{l}$ vector solution were performed in anesthetized mice using $2 \%$ isoflurane. Genotyping of mice carrying a trpm 4 (null) allele, a trpm4flox allele [38], and the a-MHC-Cre ${ }^{\text {ERT2 }}$ transgene [36] and their wild-type siblings was carried out by PCR using the primer pairs listed in Table S2. To obtain template genomic (g)DNA, ear biopsies were taken and transferred into $97.5 \mu \mathrm{l}$ of DirectPCR buffer (Viagen, USA) supplemented with $2.5 \mu \mathrm{l}$ proteinase $\mathrm{K}(10 \mathrm{mg} / \mathrm{ml}$, AppliChem, Germany) and lysed overnight at $55^{\circ} \mathrm{C}$. Proteinase $\mathrm{K}$ was denatured for $45 \mathrm{~min}$ at $85^{\circ} \mathrm{C}$. Taq PCR $(0.3 \mu \mathrm{l} \mathrm{Taq} \mathrm{DNA} \mathrm{Polymerase} \mathrm{(lab} \mathrm{made),}$ $1 \mathrm{x}$ reaction buffer $\left(100 \mathrm{mM}\right.$ Tris $\mathrm{pH} 8.3,15 \mathrm{mM} \mathrm{MgCl}_{2}$, $500 \mathrm{mM} \mathrm{KCl}$ ), $200 \mu \mathrm{M}$ dNTPs, $500 \mathrm{nM}$ primer forward and reverse and $1.0 \mu \mathrm{gDNA}$ ) was performed using the following PCR protocol: $94^{\circ} \mathrm{C} 30 \mathrm{~s}$ denaturation, 35 cycles of denaturation at $94{ }^{\circ} \mathrm{C}$ for $10 \mathrm{~s}$, annealing at $58{ }^{\circ} \mathrm{C}$ for $30 \mathrm{~s}$, and elongation at $72{ }^{\circ} \mathrm{C}$ for $30 \mathrm{~s}$.

\section{Microsomal membrane preparation}

Mice were sacrificed using cervical dislocation. The thorax was opened and the still beating heart was washed out with $0.9 \% \mathrm{NaCl}$ (Braun, Germany) injected via the apex. Mouse hearts were transferred in PBS and atria were removed. Ventricular tissue was homogenized in $1 \mathrm{ml}$ lysis buffer (100 mM TRIS-HCl, $1 \mathrm{mM} \mathrm{MgCl}_{2}$, pH 8.0 supplemented with $1 \mathrm{mM}$ iodacetamide, $1 \mathrm{mM}$ phenantholin, $0.1 \mathrm{mM}$ PMSF, $1 \mu \mathrm{g} / \mathrm{ml}$ antipain, $1 \mu \mathrm{g} / \mathrm{ml}$ leupeptin, $0.7 \mu \mathrm{g} / \mathrm{ml}$ pepstatin, $1 \mathrm{mM}$ benzamidine, $0.3 \mu \mathrm{M}$ aprotinin, AppliChem, Germany) using a 2-ml tissue grinder (Tenbroeck Tissue Grinders, Wheaton, USA). Homogenates were filled up to $3 \mathrm{ml}$ with lysis buffer and were frozen at -80 ${ }^{\circ} \mathrm{C}$ for 20 min following by thawing on ice for about $1 \mathrm{~h}$. Afterwards, $15 \mathrm{ml}$ of sucrose buffer $(0.25 \mathrm{M}$ sucrose; $10 \mathrm{mM}$ TRIS-HCl; pH 7.4 supplemented with $1 \mathrm{mM}$ iodacetamide, $1 \mathrm{mM}$ phenantholin, $0.1 \mathrm{mM}$ PMSF, $1 \mu \mathrm{g} / \mathrm{ml}$ antipain, $1 \mu \mathrm{g} / \mathrm{ml}$ leupeptin, $0.7 \mu \mathrm{g} / \mathrm{ml}$ pepstatin, $1 \mathrm{mM}$ benzamidine, $0.3 \mu \mathrm{M}$ aprotinin, Applichem, Germany) was added and the samples were centrifuged for $30 \mathrm{~min}$ at 
$6000 \mathrm{~g}$. Subsequently supernatant was centrifuged at $50.000 \mathrm{~g}$ for $1 \mathrm{~h}$ and $45 \mathrm{~min}$. The resulting microsomal membrane pellet was dissolved in 200-400 $\mu$ l sucrose buffer. Protein concentration was determined by BCA assay (Thermo Scientific, USA). Microsomal membrane fractions were supplemented with 4x Laemmli buffer (60 mM TRIS-HCl, $10 \%$ (v/v) glycerol, $5 \%(\mathrm{v} / \mathrm{v}) \beta$-mercaptoethanol, 4\% (w/v) SDS, $0.005 \%$ $(\mathrm{w} / \mathrm{v})$ bromophenol blue; $\mathrm{pH} 6.8)$ and incubated at $60{ }^{\circ} \mathrm{C}$ for $20 \mathrm{~min}$. Afterwards, microsomal membrane fractions were stored at $-80{ }^{\circ} \mathrm{C}$.

\section{Immunoblotting}

Microsomal membrane fractions $(50 \mu \mathrm{g} /$ well $)$ were loaded on a $4-12 \%$ Bis-Tris Plus or 10\% Bis-Tris Plus gel (Invitrogen, USA) followed by gel electrophoresis at $130 \mathrm{~V}$ for $90 \mathrm{~min}$. Resolved proteins were electroblotted onto a $0.45-\mu \mathrm{m}$ protran nitrocellulose membrane (GE Healthcare, USA) at $12 \mathrm{mV}$ for $60 \mathrm{~min}$. Subsequently, the membrane was blocked in 5\% nonfat milk with TBST (50 mM TRIS-HCl, $150 \mathrm{mM} \mathrm{NaCl}, 0.1 \%$ (v/v) Tween-20, $\mathrm{pH} 7.5)$ for $1 \mathrm{~h}$. Membranes were incubated in anti-GAPDH (1:500 dilution, Acris, USA), anti-TRPM4 [38] (1:100, ab578), and anti-Calnexin (1:200, ab1039) antibodies at $4{ }^{\circ} \mathrm{C}$ for $24 \mathrm{~h}$. Membranes were washed three times for $10 \mathrm{~min}$ in TBST and were then incubated in horseradish peroxidase-conjugated anti-rabbit antibody (1:50000, GE Healthcare, USA) at room temperature for $2 \mathrm{~h}$. Membranes were washed two times for $10 \mathrm{~min}$ in TBST and once for $10 \mathrm{~min}$ in TBS (50 mM TRIS-HCl, $150 \mathrm{mM} \mathrm{NaCl}, \mathrm{pH} 7.5$ ). Afterwards, membranes were incubated in SignalFire Elite ECL (Cell Signaling, USA) for $1 \mathrm{~min}$ followed by the detection of chemiluminescence using digital imaging (GE Healthcare, ImageQuant LAS 4000 mini). Protein expression levels were measured by densitometry analysis using the ImageJ software.

\section{Droplet digital PCR}

Droplet digital PCR (ddPCR) was carried out to determine the AAV genome copy number per host genome using the Magel2 gene as a diploid reference [28]. Primers and an FAM-labeled probe specific for the bGHpA (bovine growth hormone polyadenylation signal) sequence were used to determine the AAV genome copies (Table S2). Primers and an HEX-labeled probe were designed to determine the reference Magel2 gene copy number (Table S2).

Genomic DNA (gDNA) from the heart, liver, and skeletal muscle (musculus vastus lateralis) was isolated and purified by DNAeasy Blood and Tissue kit (Qiagen, USA), and then digested with HindIII (New England Biolabs, USA) for $1 \mathrm{~h}$ at $37^{\circ} \mathrm{C}$. ddPCR multiplex master mix was prepared by adding $11 \mu 12 \times$ Supermix for Probes (no UTPs) (Bio-Rad, USA), $1.1 \mu \mathrm{l} 900 \mathrm{nM}$ forward and reverse primers, $1.1 \mu \mathrm{l}$ bGHpA
Probe $(250 \mathrm{nM}), 1.1 \mu \mathrm{l}$ Magel2 Probe $(250 \mathrm{nM}), 3.3 \mu \mathrm{l}$ digested gDNA $(7.5 \mathrm{ng} / \mu \mathrm{l})$, and $3.3 \mu \mathrm{lddH} 2 \mathrm{O}$. Droplets were generated using a QX200 Droplet Generator (Bio-Rad, USA) according to the manufacturer's protocol. The resulting droplets were transferred to a 96-well PCR plate (Thermos Scientific, USA) and end point PCR was performed using a C1000 Touch PCR thermal cycler (Bio-Rad) and the following PCR program: $95^{\circ} \mathrm{C}$ for $5 \mathrm{~min}, 30$ cycles of $95^{\circ} \mathrm{C}$ for $30 \mathrm{~s}$ and $54{ }^{\circ} \mathrm{C}$ for $60 \mathrm{~s}, 4^{\circ} \mathrm{C}$ for $5 \mathrm{~min}, 90^{\circ} \mathrm{C}$ for $5 \mathrm{~min}$, and then cooling down to $4^{\circ} \mathrm{C}$. Fluorescence FAM and HEX signals of end point PCR products were analyzed using the QX200 droplet reader (Bio-Rad, USA) and the gene copy numbers were analyzed using the QuantaSoft ${ }^{\mathrm{TM}}$ software (Bio-Rad, USA, version 1.7.4.0917). The AAV genome copy number per host genome was calculated as follows: bGHpA positive droplets/(agel2 positive droplets/2).

\section{Statistical analysis}

Statistical analysis was performed using OriginPro 8.5 and Excel 2010. Data are expressed as mean \pm standard deviation (SD). Statistical significance between the two groups was tested using a two-sample $t$-test: ${ }^{* * *} p<0.0001, * * p<0.001,{ }^{*} p<$ 0.05 .

\section{Results}

\section{Maximum achievable myocardial TRPM4 protein knockdown: evaluation in Trpm $4^{\mathrm{fx} / \mathrm{fx}} / \mathrm{aMHC}^{\mathrm{AM}} \mathrm{CrT2}^{\mathrm{ERT}}$ mice}

We reasoned that complete inactivation of the Trpm4 expression in cardiomyocytes via Cre-LoxP-mediated gene deletion represents the most useful indicator for a maximum achievable TRPM4 protein knockdown in ventricular tissue. Provided that a specific antibody is available, the easiest way to estimate the amount of protein present is by Western blotting. Our experience from analysis of other low abundant membrane proteins including TRPM4 tells that a membrane protein fraction must first be prepared from cells or tissues before running these proteins on SDS-PAGE and blotting them onto a membrane for reliable detection and quantification.

For the induction of the $\alpha \mathrm{MHC}-\mathrm{Cr} \mathrm{E}^{\mathrm{ERT} 2}$ recombinase, tamoxifen was administered intraperitoneally once a day on 5 consecutive days to 6 -week-old Trpm $4^{\text {flox } / \text { flox }} / \alpha$ MHCCre ${ }^{\text {ERT2-positive }}$ mice (Fig. 1a). Trpm $4^{\text {flox } / \text { flox }} / \alpha$ MHC$\mathrm{Cre}^{\text {ERT2-negative }}$ siblings served as controls and were also treated with tamoxifen. A reduction in TRPM4 protein levels was observed in ventricular microsomal membrane fractions of $\alpha$ MHC-Cre ${ }^{\text {ERT2-positive }}$ animals already 2 weeks after the last tamoxifen injection (Fig. 1b). Quantitative Western blot 
a
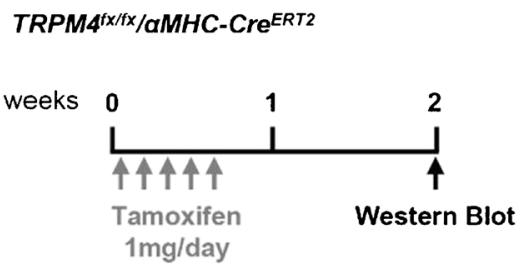

b

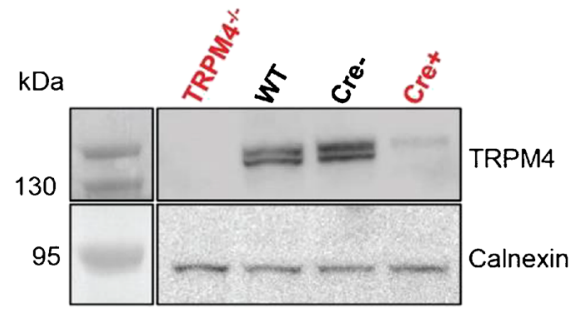

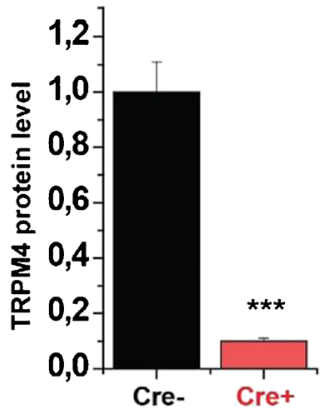

Fig. 1 Evaluation of maximum achievable myocardial TRPM4 protein knockdown in cardiomyocyte-specific TRPM4 knockout mice. a Course of tamoxifen treatment in TRPM $4^{\mathrm{fx} / \mathrm{fx}} / \alpha \mathrm{MHC}-\mathrm{Cre}^{\mathrm{ERT2} \text {-postive }}$ and TRPM $4^{\mathrm{fx} / \mathrm{fx}} / \alpha \mathrm{MHC}-\mathrm{Cre} \mathrm{ERT2}^{\mathrm{ER}-\mathrm{Cre} \text { negative }}$ mice. b Western blot analysis with anti-TRPM4 and anti-Calnexin 2 weeks after tamoxifen injections. c Quantification of the relative TRPM4 protein level in the heart of TRPM $4^{\mathrm{fx} / \mathrm{fx}} / \alpha \mathrm{MHC}$-Cre $\mathrm{ERT2}^{\mathrm{ER} \text {-positive }}(\mathrm{Cre}+)$ mice in comparison to TRPM $4^{\mathrm{fx} / \mathrm{fx}} / \alpha \mathrm{MHC}-\mathrm{Cre} \mathrm{ERT2}^{\mathrm{E} \text {-negative }}\left(\mathrm{Cre}^{-}\right)$mice. Relative protein level of TRPM4 is expressed as mean \pm SD. ${ }^{* * *} p<0.005$

positive on day 13 after selection (Fig. 2b and Fig. S1). Such cultures of B16F10 cells expressing the individual pGIPZ-shTRPM4 ${ }^{\text {miR30 }}$ constructs were expanded for Western blotting.

In total, the shTRPM4 ${ }^{\text {miR } 30}$-expressing B16F10 cells were expanded three times to obtain three independent replicates of microsomal membrane preparations and Western blot analysis (Fig. 2b-c and Fig. S2). Densitometric analysis of all three cell preparations showed that shTRPM4 ${ }^{\mathrm{miR} 30}-\# 4$ generated the strongest TRPM4 reduction of $90 \pm 6 \%$ in B16F10 cells compared to the pGIPZ-tGFP control, followed by shTRPM $4{ }^{\text {miR30 }}$-\#3 with an average TRPM4 reduction of 70 $\pm 5 \%$ and shTRPM4 $4^{\text {miR30 }}$-\#1 with a reduction of $69 \pm 14 \%$ (Fig. 2d).

\section{Myocardial TRPM4 knockdown obtained by a single- stranded AAV9-CMV-shTRPM4 ${ }^{\text {miR30 }}$-tandem construct}

To use the shTRPM4 $4^{\text {miR30 }}$ constructs for TRPM4 knockdown in murine hearts, the constructs were transferred to an adenoassociated virus (AAV) vector system, and packaged as AAV serotype 9 that leads to highest transduction efficiency in cardiomyocytes when applied at doses of $1 \times 10^{11}-1.8 \times$ $10^{12} \mathrm{vg} / \mathrm{mouse}$ via the lateral tail vein $[14,31,34]$. For the RNAi-based reduction of TRPM4, high cardiac transduction efficiency as well as a high AAV9 copy number per cardiomyocyte should be achieved by the application of $3 \times 10^{12} \mathrm{vg} /$ mouse.

For the AAV9-mediated shTRPM4 $4^{\text {miR30 }}$ transfer into the mouse heart, an AAV vector was cloned, which contained the two most promising shTRPM4 $4^{\text {miR30 }}$ sequences (shTRPM $4{ }^{\mathrm{miR} 30}$-\#3 and shTRPM $4{ }^{\mathrm{mir} 30}$-\#4) as a tandem construct (termed "shTRPM4 ${ }^{\mathrm{miR} 30}$-tandem") under the control of the cardiomyocyte-specific MLC260 promoter (Fig. 3a, upper panel). Based on the size of the expression cassette and the packaging limit of AAV, a single-stranded AAV vector (ssAAV) had to be used. 
a

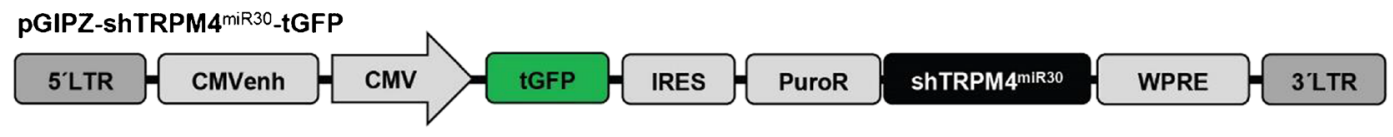

PGIPZ-tGFP

b
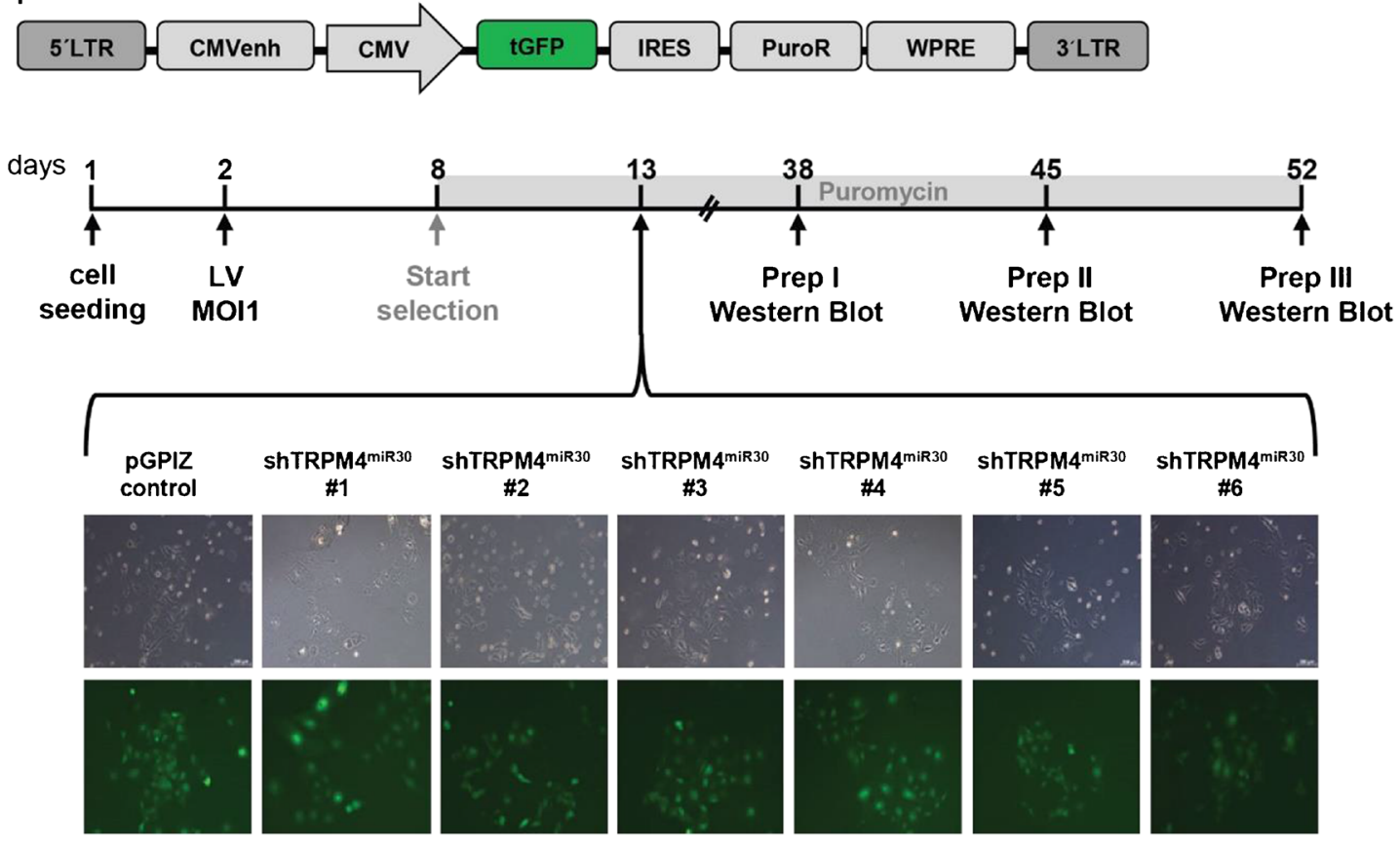

C

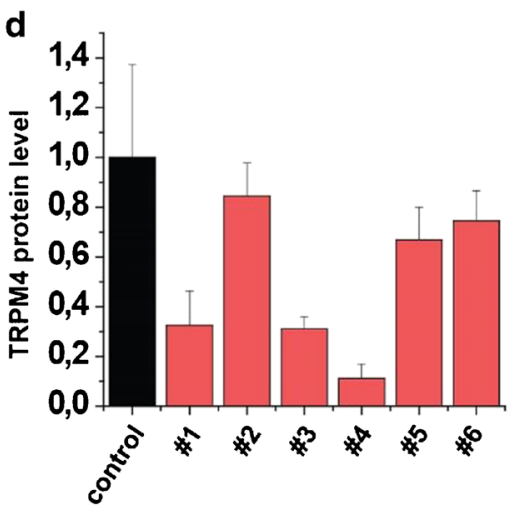

Fig. 2 Evaluation of shTRPM4 ${ }^{\mathrm{miR} 30}$ constructs in the murine B16F10 cell line. a Schematic representation of the lentiviral pGIPZshTRPM $4^{\mathrm{miR} 30}$ vector and the pGIPZ control vector. b Experimental course of lentiviral transduction and analysis of the GFP fluorescence signal in puromycin-selected B16F10 cells. $\mathbf{c}$ Western blot analysis using

Six 8-week-old male wild-type mice were treated with $3 \times$ $10^{12} \mathrm{vg} /$ mouse of the shTRPM $4{ }^{\text {miR30}}$-tandem construct. The vector was administered as single intravenous injection to the tail vein. As a control group, four untreated siblings were used, which were kept under the same conditions as the AAV9-treated mice. Western blot analysis of TRPM4 protein expression from microsomal membrane fractions of the myocardium was carried out 11 weeks after AAV9 application (Fig. 3b). Examination of the TRPM4 levels in the heart showed a significant reduction of $46 \pm 17 \%$ in TRPM 4 protein microsomal membrane fractions of B16F10 cells expressing either of the six shTRPM4 ${ }^{\mathrm{miR} 30}(\# 1-\# 6)$ constructs to evaluate shRNA ${ }^{\text {miR30}}$-mediated TRPM4 knockdown. d Quantification of the relative TRPM4 protein expression level compared to pGIPZ-tGFP control-transduced B16F10 cells

expression in the AAV9-shTRPM $4^{\text {miR30 }}$-tandem-treated mice compared to untreated siblings (Fig. 3b-c).

\section{Self-complementary scAAV9-CMV-shTRPM4 ${ }^{\text {miR30 }}$ tandem-mediated knockdown of TRPM4 in the myocardium of the mouse}

Since the ssAAV-shTRPM4 ${ }^{\text {miR30 }}$-tandem construct did not achieve a sufficiently high knockdown efficiency, we considered to use a self-complementary AAV (scAAV) that is often 
a

ssAAV9-MLC260-shTRPM4 ${ }^{\text {miR30-tandem }}$

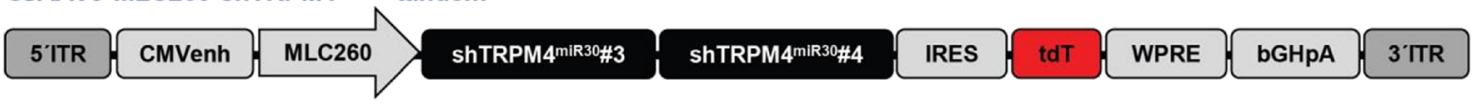

scAAV9-CMV-shTRPM4 ${ }^{\text {miR30-tandem }}$

5'ITR CMVenh CMV

scAAV9-shTRPM4-triple

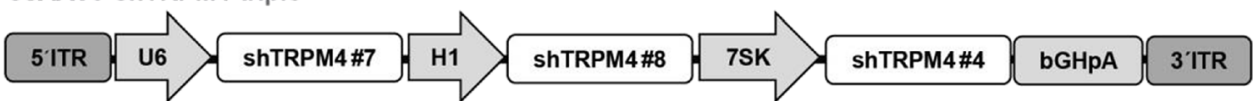

C

b

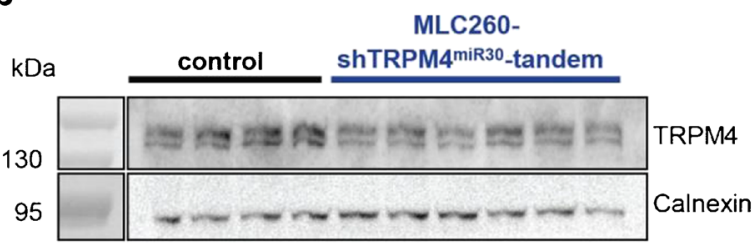

d

CMV-
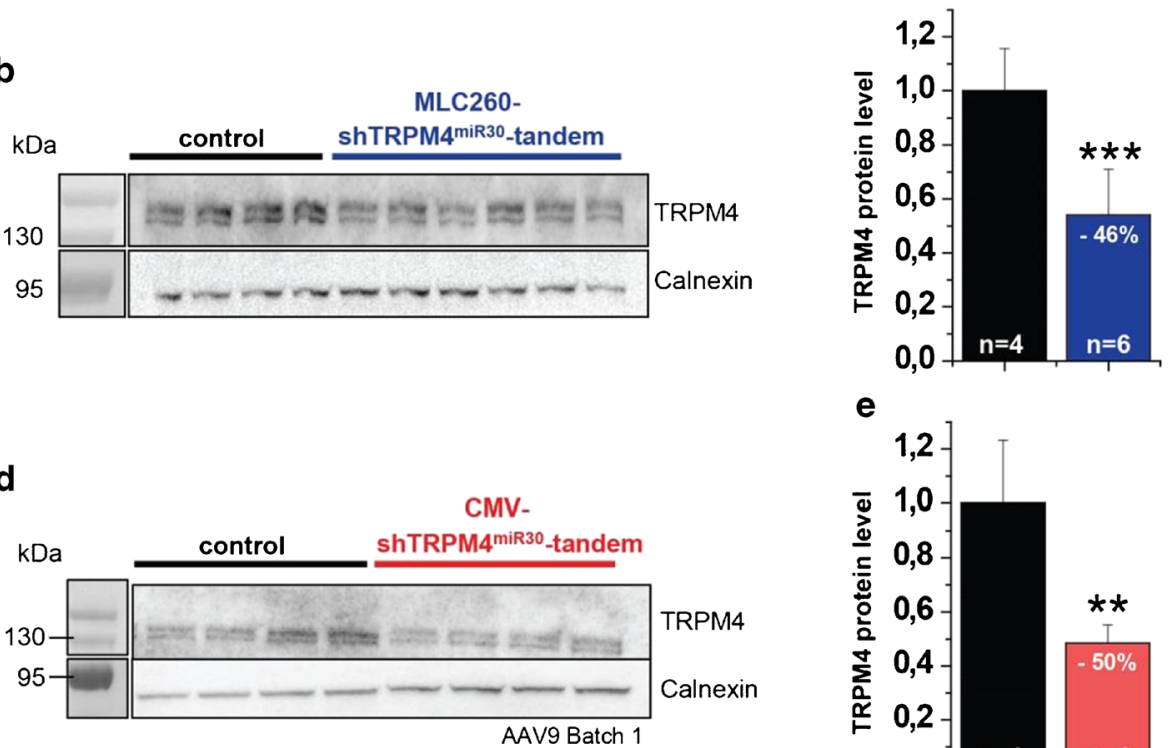

e

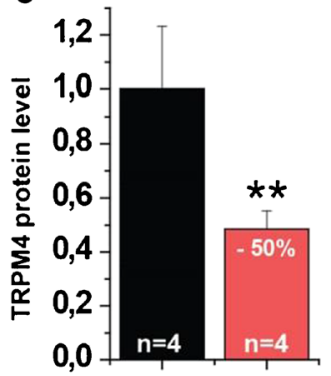

g

f
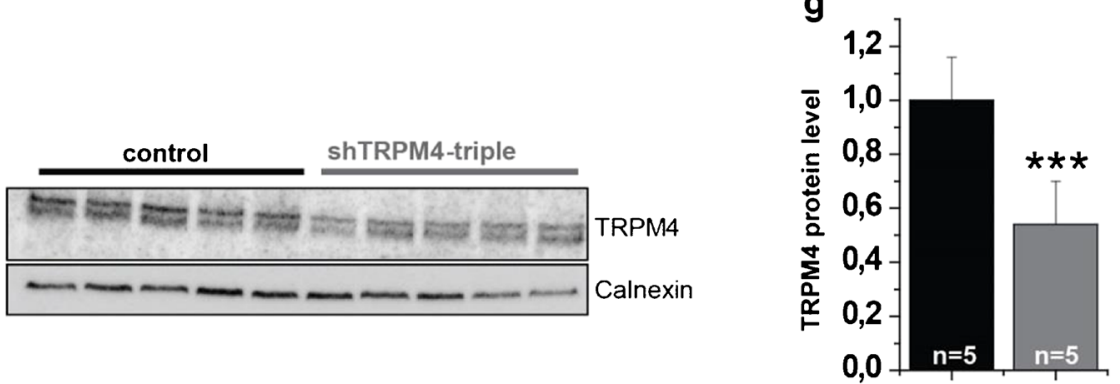

Fig. 3 Evaluation of TRPM4 knockdown-mediated AAV9-RNAi constructs in the mouse heart 11 weeks after tail vein injection. a Schematic representation of AAV-RNAi vectors used. b-g Western blot analysis with anti-TRPM4 and anti-Calnexin antibodies in ventricular microsomal membrane fractions. Single lanes represent myocardial protein fractions of individual mice. b, c Analysis of TRPM4 expression in hearts of

more efficient [25]. Due to the limited packaging capacity of the scAAV genome $(2.2 \mathrm{~kb})$, the WPRE sequence, the IRES, and the reporter gene used in the previous construct were omitted. In addition, the cardiac MLC260 promoter was replaced by the enhanced human CMV promoter (Fig. 3a, middle panel), which is considered to convey higher expression levels in mouse cardiomyocytes [27]. In an alternative
SsAAV9-MLC260-TRPM4 ${ }^{\text {miR30 }}$-tandem treated mice compared to untreated siblings. d, e Quantification of the relative TRPM4 protein level in TRPM4 protein expression in hearts of scAAV9-CMV-TRPM4 $4^{\text {miR30 }}$ tandem-treated mice. f, $\mathbf{g}$ Quantification of Western blot analysis in hearts of scAAV-shTRPM4-triple-treated mice. Relative expression of TRPM4 is expressed as mean $\pm \mathrm{SD}$. $* * * p<0.005$

approach using the same vector backbone, an expression cassette consisting of three different classic shRNAs (shTRPM4-\#7, shTRPM4-\#8, and shTRPM4-\#4) against TRPM4 under the control of three different RNA Pol III promoters was cloned (Fig. 3a, lower panel). In this construct, shTRPM4-\#4 has the same sense sequence as in shTRPM $4{ }^{\mathrm{mir} 30}$ \#4, which achieved $90 \%$ TRPM4 reduction 
in B16F10 when expressed after lentiviral transduction. The other two shRNAs (shTRPM4-\#7, shTRPM4-\#8) were generated via the online program siRNA Wizard and Block-it RNAi Designer.

The two experimental groups were treated with scAAV9shTRPM4-triple and scAAV9-shTRPM4 ${ }^{\text {miR30 }}$-tandem vector particles, respectively. Four to five 8-week-old male mice were treated with $3 \times 10^{12} \mathrm{vg} /$ mouse, and four to five untreated siblings served as controls. Vectors were again applied by single intravenous injection via the tail vein. Analysis of TRPM4 protein expression was carried out 11 weeks after AAV9 application. Microsomal membrane proteins were prepared from hearts and the TRPM4 protein levels were analyzed by Western blotting. Densitometric evaluation of the antibody stain intensities showed a significant reduction in TRPM4 protein expression by $50 \pm 7 \%$ in the heart of mice treated with the scAAV9-shTRPM $4{ }^{\text {mir30 }}$-tandem vector (Fig. $3 \mathrm{~d}$-e) and by $46 \pm$ $16 \%$ when treated with the scAAV9-shTRPM4-triple (Fig. 3fg) vector compared to untreated controls.

To further study the kinetics and longevity of shTRPM $4{ }^{\text {miR30 }}$-tandem expression and TRPM4 knockdown, animals treated with additional scAAV9-shTRPM4 ${ }^{\operatorname{mir} 30}$-tandem production batch 2 and 3 were analyzed at a later time point, 16 weeks after AAV9 application (Fig. 4), using Western blotting (Fig. 4b) to evaluate whether the TRPM4 reduction would be even more pronounced after extended shRNA expression. Indeed, densitometric analysis 16 weeks after AAV application showed a downregulation of TRPM4 expression by $61 \pm 9 \%$ in scAAV9-shTRPM4 ${ }^{\mathrm{mir} 30}$ tandem treated mice compared to untreated siblings (Fig. 4c).

\section{Optimization of the scAAV9-CMV-shTRPM4 ${ }^{\text {miR30 }}$ tandem-mediated knockdown of TRPM4 in the myocardium of the mouse}

Next, we studied the routes of AAV9 application and compared tail vein injection with AAV9 injection via the retroorbital venous plexus. In a pilot study, mice in both experimental groups were treated with $1 \times 10^{11} \mathrm{vg} /$ mouse of a scAAV9-eGFP vector (Fig. 5a). Four weeks later, transduction efficiency was assessed using a droplet digital PCR (ddPCR) copy number variation assay using gDNA of the heart and other organs with high AAV9 tropism (Fig. 5c-g). The transduction efficiency was calculated by quantifying bGHpA (Fig. 5c) and Magel2 sequences (Fig. 5d) to determine AAV viral genome and host genome copies, respectively. The analysis of normalized viral genome copies indicated that AAV application via the retro-orbital sinus yielded a 2fold higher transduction efficiency (1.2 AAV copies/host genome) in the myocardium, compared to tail vein injections in which 0.6 AAV copies/host genome were detected (Fig. 5e). In addition, the viral load in the liver, the organ with the highest AAV9 tropism, was significantly reduced by retro- orbital application (7.8 AAV copies/host genome) compared to tail vein injections (12.4 AAV copies/host genome, Fig. 5f), while the route of application showed no significant difference in skeletal muscle transduction (Fig. 5 g).

We then injected juvenile wild-type mice showing high cardiac transduction efficiency with the scAAV9. shTRPM $4{ }^{\mathrm{miR} 30}$-tandem construct via the retro-orbital sinus. As an AAV9 transduction control, siblings were treated with a scAAV9-eGFP in the same way (Fig. 5h). As before, the mice were analyzed 16 weeks after AAV9 application (Fig. 5i). Hearts were subjected to microsomal membrane purification and TRPM4 protein expression was analyzed by Western blotting (Fig. 5j). Densitometric analysis showed a significant reduction in TRPM4 protein levels by $90 \pm 7 \%$ in mice treated with scAAV9-CMV-shTRPM $4{ }^{\text {mir30 }}$-tandem compared to siblings treated with the scAAV9-eGFP control (Fig. 5k).

\section{Discussion}

Heart failure represents one of today's largest global health problems and improved therapy options are urgently required. In light of the recent clinical success of several gene therapies for monogenic diseases, cancer gene therapy is primed to be a most promising future option for the treatment of heart failure $[7,33,42]$. Target molecules for this include regulators of myocardial $\mathrm{Ca}^{2+}$ signaling, which is often derailed in the failing heart. Several previous studies have indicated that activation of the TRPM4 cation channel in cardiomyocytes negatively modulates the L-type $\mathrm{Ca}_{\mathrm{v}}$ channel-mediated $\mathrm{Ca}^{2+}$ influx. Global knockout of TRPM4 in mouse led to increased cardiac contractility under $\beta$-adrenergic stimulation, both under basal conditions and after induced myocardial infarction $[15,23,37]$. This raised the hypothesis that inhibition of TRPM4 in the heart could lead to an increase in cardiac contractility in patients with elevated catecholamine levels. So far, no specific low molecular weight TRPM4 blockers are available. Since TRPM4 is expressed not only in cardiomyocytes but also in many other cells, the use of such blockers might lead to severe adverse drug effects, such as increasing arterial blood pressure [22], triggering an anaphylactic reaction through the release of pro-inflammatory factors from mast cells [38], and increasing activation of immune cells such as dendritic cells [2] or T cells [19, 40]. Therefore, gene transfer of an RNAi sequence using recombinant AAV9 vectors to specifically target the TRPM4 transcript in cardiomyocytes may be a safer strategy. Cardiomyocytes can be transduced with high efficiency using AAV9 vectors and, with the help of cardiomyocyte-derived promoters in the corresponding vectors, the expression and the associated knockdown of TRPM4 can be confined to the contractile myocardium with only limited expression in other organs even when AAV particles are applied systemically [27, 41]. 
a

scAAV9-CMV-shTRPM4 ${ }^{\text {miR30-tandem }}$
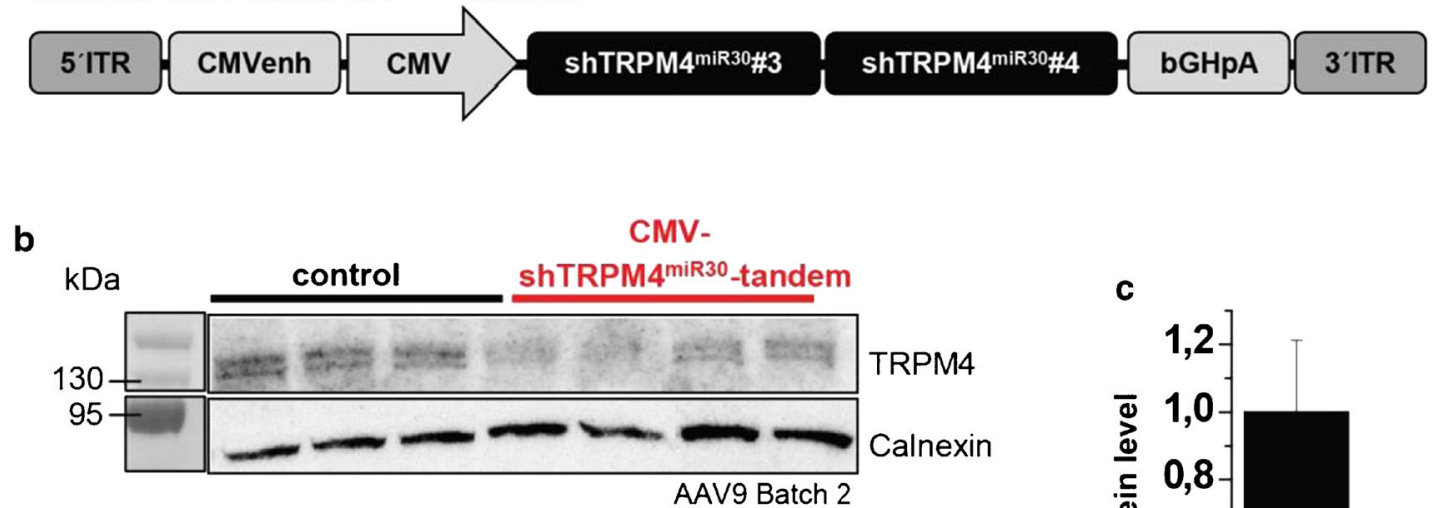

CMV-
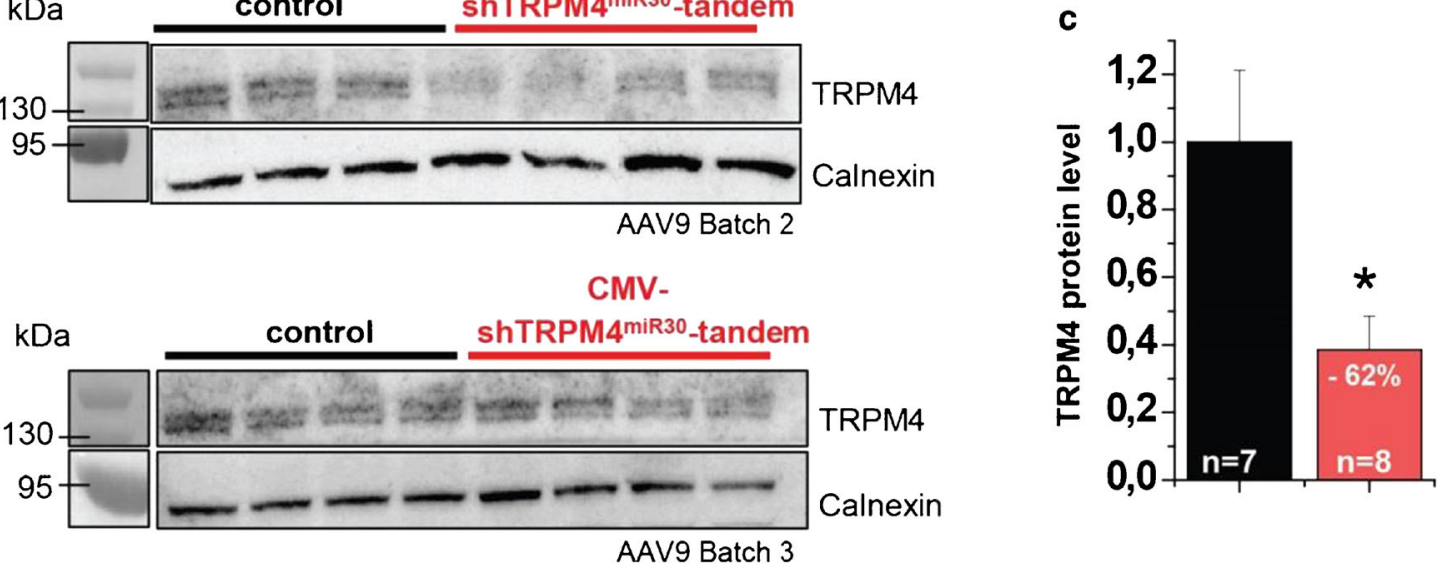

\section{AAV9 Batch 3}

Fig. 4 Evaluation of TRPM4 knockdown mediated by the scAAV9CMV-TRPM $4{ }^{\mathrm{miR} 30}$-tandem vector in the mouse heart 16 weeks after tail vein injection. a Schematic representation of the vector used. $\mathbf{b}$ Western blot analysis with anit-TRPM4 and anti-Calnexin antibodies in ventricular microsomal membrane fractions after the application of AAV9 batch 2 (upper blot) or batch 3 (lower blot). Single lanes represent

In this work, specific shRNA ${ }^{\text {miR30 }}$ sequences against the mRNA of the murine TRPM4 and distinct vector designs were evaluated. These included a microRNA-based RNAi design, which has an advantageous safety profile with respect to oversaturation of miRNA processing pathway [5, 9] and can also be expressed by tissue-specific promoters as a multishRNA ${ }^{\text {miR30 }}$ transcript [39].

At the beginning of our study, various shRNA ${ }^{\text {miR30 }}$ sequences were screened in vitro for their efficiency in degrading the murine Trpm4 mRNA and in thus causing TRPM4 knockdown. We used the murine cell line B16F10, because they were found to exhibit sufficiently high endogenous expression of TRPM4 proteins for our screening of knockout approach with shRNA ${ }^{\text {miR30 }}$ constructs. Compared to cardiomyocytes or heart tissue, the B16F10 cells are available in unlimited amounts or can be expanded indefinitely. This is important because for a reliable quantitative determination of TRPM4 protein levels using Western blotting, membrane protein fractions of B16F10 cells must first be prepared. In order to avoid a dilution of the knockdown effect after several rounds of cell division, as would have been the case with transient transfection approaches as well with an AAV6mediated gene transfer in which the transgene is not transmitted to daughter cells, the shRNA ${ }^{\text {miR30 }}$ constructs were packaged as lentiviruses. The benefit is that transduction with lentiviral vectors leads to stable integration of the transgene myocardial protein fractions of individual mice. c Quantification of the densitometric Western blot analysis of TRPM4 protein expression in hearts of scAAV9-CMV-TRPM4 ${ }^{\text {miR30 }}$-tandem treated mice compared to controls. Relative expression of TRPM4 is expressed as mean $\pm \mathrm{SD}$. $* p<0.05, * * p<0.01$

cassette into the host genome. The lentiviral approach has the additional advantage that daughter cells also carry the transgenic information and that the transduced cells can be expanded. In addition, the transgenic cassette contained a puromycin resistance gene, which allowed for a depletion of nontransduced cells before expansion. As a result, despite a low initial transduction efficiency, cells that expressed the shRNA $^{\text {miR30 }}$ construct could be specifically expanded and analyzed, which alleviated the expression analysis of low abundant TRPM4 proteins. Using the lentiviral-based in vitro screen, we identified three shRNA ${ }^{\text {miR30 }}$ sequences from a total of six, which reduced the endogenous TRPM4 protein level by up to $90 \pm 6 \%$.

The primary goal of this work was to downregulate the TRPM4 protein level in the adult murine heart to a maximum extent that is comparable to complete gene deletion as obtained by Cre-loxP-dependent TRPM4 deletion in cardiomyocytes. The two most potent shRNA ${ }^{\text {miR30 }}$ sequences from the in vitro screen were therefore selected for an in vivo TRPM4 knockdown strategy suitable for therapeutic approaches and subcloned as a tandem construct under the control of the cardiomyocyte-specific MLC260 promoter. For in vivo gene transfer, we chose AAV9 vectors at a dose of 3 $\times 10^{12}$ viral genomes per mouse and initially tested application via intravenous administration, since this strategy has already been described to achieve homogeneous and effective 
a

SCAAV9-CMV-eGFP

5'TR CMVenh

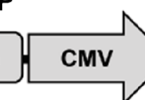

$\sqrt{2}$

eGFP

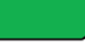

C

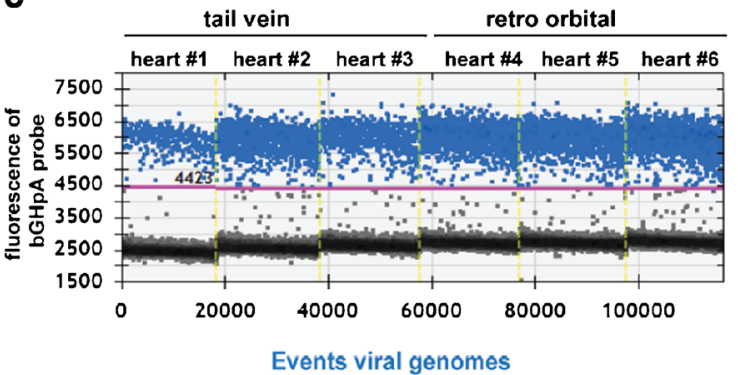

e

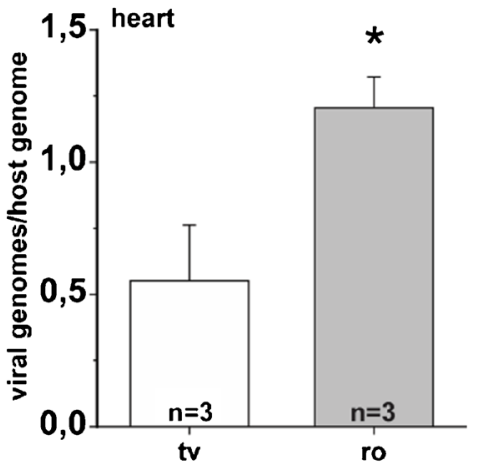

h

SCAAV9-CMV-shTRPM4 ${ }^{\text {miR30-tandem }}$ f

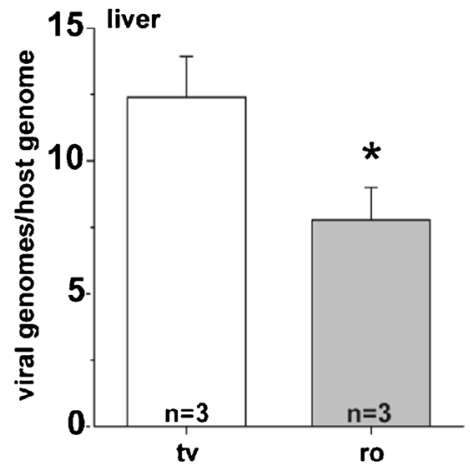

b

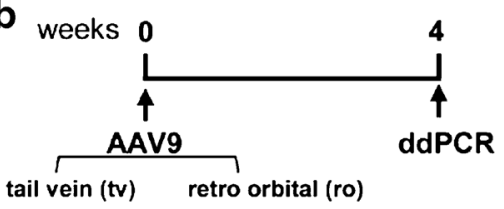

d

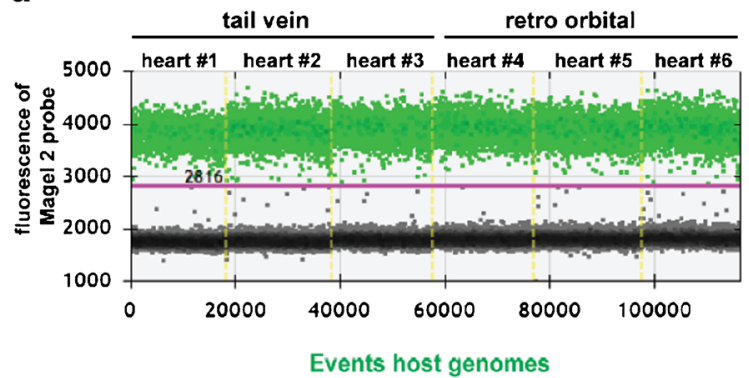

g

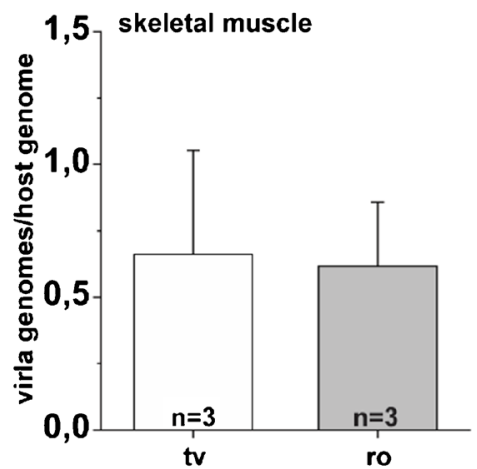

SCAAV9-CMV-eGFP

5'ITR CMVenh CMV eGFP bGHpA 3'TTR

i

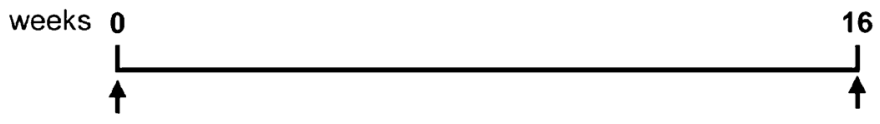

AAV9

retro orbital

j

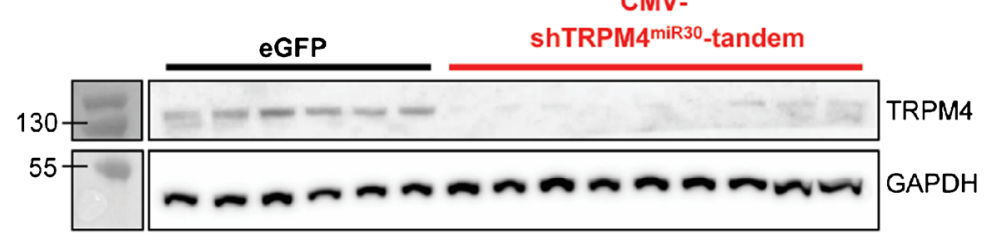

Western Blot

\section{ShTRPM4 $4^{\text {miR } 30 \# 3}$ shTRPM4 $4^{\text {miR } 30 \# 4}$ bGHPA 3 3ITR}

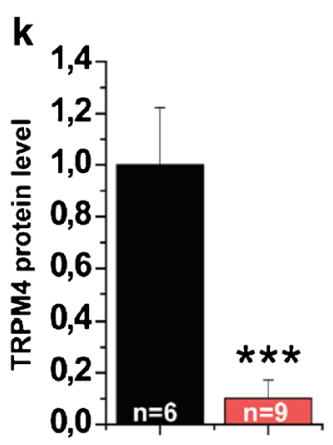


Fig. 5 AAV9 application via the retro-orbital sinus elevates cardiac transduction efficiency and results in efficient scAAV9-CMVshTRPM $4^{\text {miR30 }}$-tandem-mediated TRPM4 knockdown in the moue heart. a Comparison of the intravenous AAV9 application methods via the tail vein (sv) and the retro-orbital sinus (ro) of the mouse. b Schematic representation of the experimental course. c-g Determination of AAV9 transduction efficiency using droplet digital PCR (ddPCR). Droplet count view for $\mathbf{c}$ viral genomes and $\mathbf{d}$ host genomes in hearts injected via tail vein or retro-orbital sinus. Positive droplets are displayed in blue (viral genome counts of the AAV containing bGHpA, bovine growth hormone polyadenylation signal sequence) or green (host genome counts of the Magel2 reference gene) and negative droplets in black. AAV9 transduction efficiency was quantified as viral genomes/host genome in the $\mathbf{e}$ heart, f liver, and $\mathbf{g}$ skeletal muscle (musculus vastus lateralis). h Schematic representation of the scAAV-CMV-shTRPM $4{ }^{\text {miR } 30}$-tandem and scAAV9-CMV-GFP control vector used. i Analysis of TRPM4 expression followed 16 weeks after AAV9 application. $\mathbf{j}$ Western blot analysis with anti-TRPM4 and anti-GAPDH antibodies of ventricular microsomal membrane fractions. Single lanes represent myocardial protein fractions of individual mice. $\mathbf{k}$ Quantification of the relative TRPM4 protein in hearts of scAAV9-CMV-TRPM $4{ }^{\mathrm{miR} 30}$-tandem-treated mice compared to AAV9-CMV-GFP treated controls. Relative expression of TRPM4 is expressed as mean \pm SD. $* p<0.05, * * * p<0.005$

transduction efficiency in the left ventricle $[3,14,21,34,41$, 43].

In a first series of experiments, an ssAAV genome was used, which contained the shRNA ${ }^{\text {miR30 }}$-tandem construct. TRPM4 knockdown efficiency was less than $50 \%$, 11 weeks after AAV9 application. Since this degree of reduction is probably too low to expect an increased cardiac contractility, various features of the AAV-shRNA construct were further optimized. We aimed to enhance knockdown efficiency by the use of scAAV vectors which can achieve a faster and more efficient expression of the transgenic cassette [25]. Because scAAVs allow only reduced packaging capacity, we had to remove the expression reporter (tdTomato) as well as the WPRE sequence so that the transgene cassette was reduced to the promoter, the shRNA ${ }^{\mathrm{miR}}$-tandem, and the polyadenylation sequence.

Furthermore, an increase in the expression level of the shRNA ${ }^{\text {miR30}}$-tandem should be achieved by using the CMV RNA Pol II promoter. Compared to promoters derived from cardiomyocytes, the CMV promoter mediates a significantly higher expression level in the mouse myocardium [6, 27, 34]. However, the degree of TRPM4 downregulation using this shRNA ${ }^{\text {miR30 }}$-tandem construct in the scAAV backbone under the control of the CMV promotor was also only in the range of $50 \%$ after 11 weeks, and slightly improved $(\sim 60 \%)$ when evaluated 16 weeks after vector application, supporting the idea that extending the life-span period is beneficial. In addition to the shRNAmiR30 RNAi approach, a classical shRNA design was developed as an alternative RNAi approach and tested directly in vivo without prior in vitro evaluation. However, the analysis of the
shRNA-triple construct did not increase the TRPM4 knockdown efficiency compared to the previous ssAAV-shRNA ${ }^{\text {miR30 }}$-tandem vector. Due to concerns about shRNA toxicity and the restriction to expression from RNA Pol III promoters, no further test groups were treated with the classic shRNA-triple vector in order to increase the TRPM4 knockdown.

Since the knockdown potential of shRNA-\#4 was in the range of $90 \%$ in $\mathrm{B} 16 \mathrm{~F} 10$ cells, we reasoned that the lower knockdown efficiency in the heart observed so far might result from inefficient delivery to the heart and cardiomyocytes by application to the peripheral circulation via the tail vein. We therefore tested whether injection via the retro-orbital sinus may lead to improved transduction efficiency with a given AAV9 vector. In a first experiment, we thus compared head to head the application via the retro-orbital sinus with injections via the lateral tail vein and found 2-fold more AAV viral copies per host genome with the application route via the retro-orbital sinus. This result strengthens the hypotheses that the injection via the retro-orbital sinus improves cardiac AAV9 transduction by allowing the vector solution to reach the heart more directly without significant dilution in the circulation. The reduced transduction efficiency in the liver observed with injection via the retro-orbital route is an additional argument for this hypothesis. Since the retro-orbital injection can already be carried out accurately in 3-week-old mice, juvenile mice were used in order to minimize the distribution volume of the vector solution as much as possible although it has been reported that the AAV vector transduction is more stable in adult animals [12]. Indeed, a $\sim 90 \%$ reduction in TRPM4 protein expression was achieved with the latter approach.

Given that no more than $90 \%$ reduction in the ventricle was obtained by Cre-loxP-mediated gene deletion in a cardiomyocyte-specific knockout mouse, it can be assumed that the improved AAV9-shTRPM4 $4^{\mathrm{miR} 30}$-tandem-induced knockdown of TRPM4 in cardiomyocytes should be close to $100 \%$. This result suggests that the retro-orbital application route in combination with the small distribution volume of juvenile mice achieves an improved AAV9 transfer into the heart of the animals and consequently leads to an increased cardiac TRPM4 knockdown. This gene silencing strategy can now be used to treat preclinical mouse models of acute and chronic systolic heart failure in order to restore cardiac contractile function.

Taken together, we have successfully developed a highly efficient AAV9-mediated RNAi strategy to achieve a vectorinduced knockdown of TRPM4 in the adult mouse heart. Combining the robust AAV9-shRNA ${ }^{\text {miR30 }}$ design with an optimal route of application yielded a 90\% reduction of TRPM4 
in the mouse myocardium. This strategy represents a promising approach to test whether TRPM4 knockdown leads to an increase in inotropic response in healthy animals and particularly in heart failure models. If successful, the strategy could be transferred to patients with heart failure associated with elevated catecholamine levels.

Supplementary Information The online version contains supplementary material available at https://doi.org/10.1007/s00424-021-02521-6.

Acknowledgements Open Access funding enabled and organized by Projekt DEAL. We are thankful to Stefan Offermanns (Max-PlanckInstitute for Heart and Lung Research, Germany) who kindly provided the $\alpha \mathrm{MHC} / \mathrm{CreERT} 2$ mice, and to Christin Richter, Manuela Ritzal, Hans-Peter Gensheimer, and the team from the Interfakultäre Biomedizinische Forschungseinrichtung (IBF) from the Heidelberg University for the expert technical assistance.

Author contribution Rebekka Medert: conceptualization, data curation, formal analysis, validation, investigation, visualization, writing - original draft, writing - review and editing

Andreas Jungmann: conceptualization, methodology, writingreview and editing

Staffan Hildebrand: methodology, lentivirus production, writingreview and editing

Dirk Grimm: conceptualization, methodology, writing — review and editing

Veit Flockerzi: methodology, TRPM4 antibody, writing — review and editing

Oliver J. Müller: conceptualization, methodology, writing-review and editing

Martin Busch: conceptualization, methodology, writing - review and editing

Patrick Most: conceptualization, methodology, supervision, writingreview and editing

Dagmar Schumacher: conceptualization, formal analysis, supervision, validation, investigation, writing - review and editing

Marc Freichel: conceptualization, formal analysis, supervision, funding acquisition, investigation, writing — original draft, project administration, writing — review and editing

Funding This research was funded by the DZHK (German Centre for Cardiovascular Research), the BMBF (German Ministry of Education and Research), a Baden-Württemberg federal state innovation fund, the Transregional Collaborative Research Centers 152 and 179 (TRR-152 and -179), and the collaborative Research Center 1118 (SFB 1118).

Data and materials availability All data that support the findings of this study are available in this study within the manuscript and/or its supplementary materials.

\section{Declarations}

Competing interests Patrick Most, Martin Busch, and Dirk Grimm are co-founders and shareholders of the company AaviGen GmbH. All other authors declare no conflict of interest.

Open Access This article is licensed under a Creative Commons Attribution 4.0 International License, which permits use, sharing, adaptation, distribution and reproduction in any medium or format, as long as you give appropriate credit to the original author(s) and the source, provide a link to the Creative Commons licence, and indicate if changes were made. The images or other third party material in this article are included in the article's Creative Commons licence, unless indicated otherwise in a credit line to the material. If material is not included in the article's Creative Commons licence and your intended use is not permitted by statutory regulation or exceeds the permitted use, you will need to obtain permission directly from the copyright holder. To view a copy of this licence, visit http://creativecommons.org/licenses/by/4.0/.

\section{References}

1. Adams D, Gonzalez-Duarte A, O'Riordan WD, Yang CC, Ueda M, Kristen AV, Tournev I, Schmidt HH, Coelho T, Berk JL, Lin KP, Vita G, Attarian S, Plante-Bordeneuve V, Mezei MM, Campistol JM, Buades J, Brannagan TH 3rd, Kim BJ, Oh J, Parman Y, Sekijima Y, Hawkins PN, Solomon SD, Polydefkis M, Dyck PJ, Gandhi PJ, Goyal S, Chen J, Strahs AL, Nochur SV, Sweetser MT, Garg PP, Vaishnaw AK, Gollob JA, Suhr OB (2018) Patisiran, an RNAi therapeutic, for hereditary transthyretin amyloidosis. N Engl J Med 379:11-21. https://doi.org/10.1056/NEJMoa1716153

2. Barbet G, Demion M, Moura IC, Serafini N, Leger T, Vrtovsnik F, Monteiro RC, Guinamard R, Kinet JP, Launay P (2008) The calcium-activated nonselective cation channel TRPM4 is essential for the migration but not the maturation of dendritic cells. Nat Immunol 9:1148-1156. https://doi.org/10.1038/ni.1648

3. Bish LT, Morine K, Sleeper MM, Sanmiguel J, Wu D, Gao G, Wilson JM, Sweeney HL (2008) Adeno-associated virus (AAV) serotype 9 provides global cardiac gene transfer superior to AAV1, AAV6, AAV7, and AAV8 in the mouse and rat. Hum Gene Ther 19:1359-1368. https://doi.org/10.1089/hum.2008.123

4. Borner K, Kienle E, Huang LY, Weinmann J, Sacher A, Bayer P, Stullein C, Fakhiri J, Zimmermann L, Westhaus A, Beneke J, Beil N, Wiedtke E, Schmelas C, Miltner D, Rau A, Erfle H, Krausslich HG, Muller M, Agbandje-McKenna M, Grimm D (2020) Prearrayed Pan-AAV peptide display libraries for rapid single-round screening. Mol Ther 28:1016-1032. https://doi.org/10.1016/j. ymthe.2020.02.009

5. Boudreau RL, Martins I, Davidson BL (2009) Artificial microRNAs as siRNA shuttles: improved safety as compared to shRNAs in vitro and in vivo. Mol Ther 17:169-175. https://doi. org/10.1038/mt.2008.231

6. Geisler A, Jungmann A, Kurreck J, Poller W, Katus HA, Vetter R, Fechner H, Muller OJ (2011) microRNA122-regulated transgene expression increases specificity of cardiac gene transfer upon intravenous delivery of AAV9 vectors. Gene Ther 18:199-209. https:// doi.org/10.1038/gt.2010.141

7. Greenberg B (2017) Gene therapy for heart failure. Trends Cardiovasc Med 27:216-222. https://doi.org/10.1016/j.tcm.2016. 11.001

8. Grieger JC, Choi VW, Samulski RJ (2006) Production and characterization of adeno-associated viral vectors. Nat Protoc 1:14121428. https://doi.org/10.1038/nprot.2006.207

9. Grimm D (2011) The dose can make the poison: lessons learned from adverse in vivo toxicities caused by RNAi overexpression. Silence 2:8. https://doi.org/10.1186/1758-907X-2-8

10. Grimm D, Kay MA (2007) Therapeutic application of RNAi: is mRNA targeting finally ready for prime time? J Clin Invest 117 : 3633-3641. https://doi.org/10.1172/JCI34129

11. Grimm D, Streetz KL, Jopling CL, Storm TA, Pandey K, Davis CR, Marion P, Salazar F, Kay MA (2006) Fatality in mice due to oversaturation of cellular microRNA/short hairpin RNA pathways. Nature 441:537-541. https://doi.org/10.1038/nature04791 
12. Han SO, Li S, McCall A, Arnson B, Everitt JI, Zhang H, Young SP, ElMallah MK, Koeberl DD (2020) Comparisons of infant and adult mice reveal age effects for liver depot gene therapy in Pompe disease. Mol Ther Methods Clin Dev 17:133-142. https://doi.org/10. 1016/j.omtm.2019.11.020

13. Hovingh GK, Lepor NE, Kallend D, Stoekenbroek RM, Wijngaard PLJ, Raal FJ (2020) Inclisiran durably lowers low-density lipoprotein cholesterol and proprotein convertase subtilisin/kexin type 9 expression in homozygous familial hypercholesterolemia: the ORION-2 Pilot Study. Circulation 141:1829-1831. https://doi. org/10.1161/CIRCULATIONAHA.119.044431

14. Inagaki K, Fuess S, Storm TA, Gibson GA, McTiernan CF, Kay MA, Nakai H (2006) Robust systemic transduction with AAV9 vectors in mice: efficient global cardiac gene transfer superior to that of AAV8. Mol Ther 14:45-53. https://doi.org/10.1016/j.ymthe. 2006.03.014

15. Jacobs G, Oosterlinck W, Dresselaers T, Geenens R, Kerselaers S, Himmelreich U, Herijgers P, Vennekens R (2015) Enhanced betaadrenergic cardiac reserve in Trpm4(-)/(-) mice with ischaemic heart failure. Cardiovasc Res 105:330-339. https://doi.org/10. 1093/cvr/cvv009

16. Jungmann A, Leuchs B, Katus HA, Rommelaere J, Muller OJ (2017) Protocol for efficient generation and characterization of adeno-associated viral (AAV) vectors. Hum Gene Ther Methods. https://doi.org/10.1089/hum.2017.192

17. Kruse M, Schulze-Bahr E, Corfield V, Beckmann A, Stallmeyer B, Kurtbay G, Ohmert I, Schulze-Bahr E, Brink P, Pongs O (2009) Impaired endocytosis of the ion channel TRPM4 is associated with human progressive familial heart block type I. J Clin Invest 119: 2737-2744. https://doi.org/10.1172/JCI38292

18. Launay P, Fleig A, Perraud AL, Scharenberg AM, Penner R, Kinet JP (2002) TRPM4 is a Ca2+-activated nonselective cation channel mediating cell membrane depolarization. Cell 109:397-407. https:// doi.org/10.1016/s0092-8674(02)00719-5

19. Launay P, Cheng H, Srivatsan S, Penner R, Fleig A, Kinet JP (2004) TRPM4 regulates calcium oscillations after T cell activation. Science 306:1374-1377. https://doi.org/10.1126/science.1098845

20. Liu H, El Zein L, Kruse M, Guinamard R, Beckmann A, Bozio A, Kurtbay G, Megarbane A, Ohmert I, Blaysat G, Villain E, Pongs O, Bouvagnet P (2010) Gain-of-function mutations in TRPM4 cause autosomal dominant isolated cardiac conduction disease. Circ Cardiovasc Genet 3:374-385. https://doi.org/10.1161/ CIRCGENETICS.109.930867

21. Long C, Amoasii L, Mireault AA, McAnally JR, Li H, SanchezOrtiz E, Bhattacharyya S, Shelton JM, Bassel-Duby R, Olson EN (2016) Postnatal genome editing partially restores dystrophin expression in a mouse model of muscular dystrophy. Science 351: 400-403. https://doi.org/10.1126/science.aad5725

22. Mathar I, Vennekens R, Meissner M, Kees F, Van der Mieren G, Camacho Londono JE, Uhl S, Voets T, Hummel B, van den Bergh A, Herijgers P, Nilius B, Flockerzi V, Schweda F, Freichel M (2010) Increased catecholamine secretion contributes to hypertension in TRPM4-deficient mice. J Clin Invest 120:3267-3279. https://doi.org/10.1172/JCI41348

23. Mathar I, Kecskes M, Van der Mieren G, Jacobs G, Camacho Londono JE, Uhl S, Flockerzi V, Voets T, Freichel M, Nilius B, Herijgers P, Vennekens R (2014) Increased beta-adrenergic inotropy in ventricular myocardium from Trpm4-/- mice. Circ Res 114:283-294. https://doi.org/10.1161/CIRCRESAHA.114. 302835

24. McBride JL, Boudreau RL, Harper SQ, Staber PD, Monteys AM, Martins I, Gilmore BL, Burstein H, Peluso RW, Polisky B, Carter BJ, Davidson BL (2008) Artificial miRNAs mitigate shRNAmediated toxicity in the brain: implications for the therapeutic development of RNAi. Proc Natl Acad Sci U S A 105:5868-5873. https://doi.org/10.1073/pnas.0801775105
25. McCarty DM, Monahan PE, Samulski RJ (2001) Selfcomplementary recombinant adeno-associated virus (scAAV) vectors promote efficient transduction independently of DNA synthesis. Gene Ther 8:1248-1254. https://doi.org/10.1038/sj.gt.3301514

26. Medert R, Pironet A, Bacmeister L, Segin S, Londono JEC, Vennekens R, Freichel M (2020) Genetic background influences expression and function of the cation channel TRPM4 in the mouse heart. Basic Res Cardiol 115:70. https://doi.org/10.1007/s00395020-00831-x

27. Muller OJ, Leuchs B, Pleger ST, Grimm D, Franz WM, Katus HA, Kleinschmidt JA (2006) Improved cardiac gene transfer by transcriptional and transductional targeting of adeno-associated viral vectors. Cardiovasc Res 70:70-78. https://doi.org/10.1016/j. cardiores.2005.12.017

28. Nakagaki A, Urakawa A, Hirano S, Anami T, Kishino T (2018) Application of droplet digital PCR in the analysis of genome integration and organization of the transgene in BAC transgenic mice. Sci Rep 8:6638. https://doi.org/10.1038/s41598-018-25001-x

29. Nelson PL, Zolochevska O, Figueiredo ML, Soliman A, Hsu WH, Feng JM, Zhang H, Cheng H (2011) Regulation of Ca(2+)-entry in pancreatic alpha-cell line by transient receptor potential melastatin 4 plays a vital role in glucagon release. Mol Cell Endocrinol 335: 126-134. https://doi.org/10.1016/j.mce.2011.01.007

30. Nelson P, Ngoc Tran TD, Zhang H, Zolochevska O, Figueiredo M, Feng JM, Gutierrez DL, Xiao R, Yao S, Penn A, Yang LJ, Cheng H (2013) Transient receptor potential melastatin 4 channel controls calcium signals and dental follicle stem cell differentiation. Stem Cells 31:167-177. https://doi.org/10.1002/stem.1264

31. Pacak CA, Mah CS, Thattaliyath BD, Conlon TJ, Lewis MA, Cloutier DE, Zolotukhin I, Tarantal AF, Byrne BJ (2006) Recombinant adeno-associated virus serotype 9 leads to preferential cardiac transduction in vivo. Circ Res 99:e3-e9. https://doi.org/ 10.1161/01.RES.0000237661.18885.f6

32. Pacak CA, Sakai Y, Thattaliyath BD, Mah CS, Byrne BJ (2008) Tissue specific promoters improve specificity of AAV9 mediated transgene expression following intra-vascular gene delivery in neonatal mice. Genet Vacc Ther 6:13. https://doi.org/10.1186/14790556-6-13

33. Pleger ST, Brinks H, Ritterhoff J, Raake P, Koch WJ, Katus HA, Most P (2013) Heart failure gene therapy: the path to clinical practice. Circ Res 113:792-809. https://doi.org/10.1161/ CIRCRESAHA.113.300269

34. Prasad KM, Xu Y, Yang Z, Acton ST, French BA (2011) Robust cardiomyocyte-specific gene expression following systemic injection of AAV: in vivo gene delivery follows a Poisson distribution. Gene Ther 18:43-52. https://doi.org/10.1038/gt.2010.105

35. Stallmeyer B, Zumhagen S, Denjoy I, Duthoit G, Hebert JL, Ferrer X, Maugenre S, Schmitz W, Kirchhefer U, Schulze-Bahr E, Guicheney P, Schulze-Bahr E (2012) Mutational spectrum in the $\mathrm{Ca}(2+)$-activated cation channel gene TRPM4 in patients with cardiac conductance disturbances. Hum Mutat 33:109-117. https:// doi.org/10.1002/humu.21599

36. Takefuji M, Wirth A, Lukasova M, Takefuji S, Boettger T, Braun T, Althoff T, Offermanns S, Wettschureck N (2012) G(13)-mediated signaling pathway is required for pressure overload-induced cardiac remodeling and heart failure. Circulation 126:1972-1982. https://doi.org/10.1161/CIRCULATIONAHA.112.109256

37. Uhl S, Mathar I, Vennekens R, Freichel M (2014) Adenylyl cyclase-mediated effects contribute to increased Isoprenalineinduced cardiac contractility in TRPM4-deficient mice. J Mol Cell Cardiol 74C:307-317. https://doi.org/10.1016/j.yjmcc.2014. 06.007

38. Vennekens R, Olausson J, Meissner M, Bloch W, Mathar I, Philipp SE, Schmitz F, Weissgerber P, Nilius B, Flockerzi V, Freichel M (2007) Increased IgE-dependent mast cell activation and anaphylactic responses in mice lacking the calcium-activated nonselective 
cation channel TRPM4. Nat Immunol 8:312-320. https://oi.org/ 10.1038/ni1441

39. Wang J, Theunissen TW, Orkin SH (2007) Site-directed, virus-free, and inducible RNAi in embryonic stem cells. Proc Natl Acad Sci U S A 104:20850-20855. https://doi.org/10.1073/pnas.0710565105

40. Weber KS, Hildner K, Murphy KM, Allen PM (2010) Trpm4 differentially regulates $\mathrm{Th} 1$ and $\mathrm{Th} 2$ function by altering calcium signaling and NFAT localization. J Immunol 185:2836-2846. https:// doi.org/10.4049/jimmunol.1000880

41. Werfel S, Jungmann A, Lehmann L, Ksienzyk J, Bekeredjian R, Kaya Z, Leuchs B, Nordheim A, Backs J, Engelhardt S, Katus HA, Muller OJ (2014) Rapid and highly efficient inducible cardiac gene knockout in adult mice using AAV-mediated expression of Cre recombinase. Cardiovasc Res 104:15-23. https://doi.org/10.1093/ $\mathrm{cvr} / \mathrm{cvu} 174$

42. Zhang Y, Li H, Min YL, Sanchez-Ortiz E, Huang J, Mireault AA, Shelton JM, Kim J, Mammen PPA, Bassel-Duby R, Olson EN
(2020) Enhanced CRISPR-Cas9 correction of Duchenne muscular dystrophy in mice by a self-complementary AAV delivery system. Sci Adv 6:eaay6812. https://doi.org/10.1126/sciadv.aay6812

43. Zincarelli C, Soltys S, Rengo G, Koch WJ, Rabinowitz JE (2010) Comparative cardiac gene delivery of adeno-associated virus serotypes 1-9 reveals that AAV6 mediates the most efficient transduction in mouse heart. Clin Transl Sci 3:81-89. https://doi.org/10. 1111/j.1752-8062.2010.00190.x

44. Zolotukhin S, Byrne BJ, Mason E, Zolotukhin I, Potter M, Chesnut K, Summerford C, Samulski RJ, Muzyczka N (1999) Recombinant adeno-associated virus purification using novel methods improves infectious titer and yield. Gene Ther 6:973-985. https://doi.org/10. 1038/sj.gt.3300938

Publisher's note Springer Nature remains neutral with regard to jurisdictional claims in published maps and institutional affiliations. 